\title{
$\mathrm{eICIC}$ 가 적용된 이종 셀룰러 망을 위한 부하 분산 기법
}

\author{
홍 명 훈, 박 승 영
}

\section{Load Balancing Scheme for Heterogeneous Cellular Networks Using e-ICIC}

\author{
Myung-hoon Hong', Seung-young Park \\ 요 약
}

기존의 매크로 셀룰러 망 환경은 공간 재사용의 한계로 인해 최근 급증하는 데이터 트래픽을 제대로 지원할 수 없게 되었다. 이 문제를 극복하기 위해 매크로 셀룰러 망위에 스몰 셀이 설치되어 적극적인 공간 재사용이 가능한 이종 셀룰러 망이 등장하게 되었다. 하지만, 매크로 셀과 스몰 셀 사이의 전송전력 차이로 인해 매크로 셀에 집중 된 부하를 스몰 셀로 충분히 분산 시킬 수 없었다. 따라서, 프레임의 일정구간에서 매크로 셀의 전송전력을 차단 하는 almost blank subframe (ABS) 와 스몰 셀 커버리지를 확장하여 사용자 부하를 스몰 셀로 강제 분산시키는 cell range expansion을 결합한 enhanced inter-cell interference coordination (eICIC) 기법이 제안되었다. 그러나, 이러한 eICIC 기법만으로는 효과적인 부하 분산을 달성하기 어렵다. 본 논문에서는 eICIC 기법이 적용된 이종 셀 룰러 망 환경에서 비례공정을 향상시키는 부하 분산 기법을 제안한다. 구체적으로 제안된 기법은 탐욕 알고리즘 기반의 사용자의 소속 기지국 전환과 $\mathrm{ABS}$ 구간비율 갱신을 재귀적으로 결합하여 부하 분산을 실행한다.

Key Words : elCIC, ABS, cell range expansion, load balance, HetNet

\section{ABSTRACT}

Recently, heterogeneous networks consisting of small-cells on top of traditional macro-cellular network has attracted much attention, because traditional macro-cellular network is not suitable to support more demanding mobile data traffic due to its limitation of spatial reuse. However, due to the transmit power difference between macro- and small-cells, most users are associated with macro-cells rather than small-cells. To solve this problem, enhanced inter-cell interference coordination (eICIC) has been introduced. Particularly, in eICIC, the small-cell coverage is forcibly expanded to associate more users with small-cells. Then, to avoid cross-tier interference from macro-cells, these users are allowed to receive the data during almost blank subframe (ABS) in which macro-cells almost remain silent. However, this approach is not sufficient to balance the load between macroand small-cells because it only expands the small-cell coverage. In this paper, we propose a load balance scheme improving proportional fairness for heterogeneous networks employing eICIC. In particular, the proposed scheme combines the greedy-based user association and the ABS rate determination in a recursive manner to perform the load balance.

※ This research was supported by Basic Science Research Program through the National Research Foundation of Korea (NRF) funded by the Ministry of Science, ICT \& Future Planning (NRF-2012R1A1A1001769) and 2013 Research Grant from Kangwon National University (No. 120131440).

- First Author : Kangwon National University, School of Information Technology, hoons@kangwon.ac.kr, 학생회원

- Corresponding Author : Kangwon National University, School of Information Technology, s.young.park@kangwon.ac.kr, 종신회원 논문번호 : KICS2014-01-026, Received January 30, 2014; Revised April 4, 2014; Accepted April 22, 2014 


\section{I. 서 론}

2017 년 모바일 디바이스에서 요구되는 데이터 트 래픽은 2012년에 비해 약 13 배 증가할 것으로 예상된 다 ${ }^{[1]}$. 하지만, 기존의 매크로 셀룰러 망에서는 공간 재 사용의 한계로 인해 기지국과 사용자 사이의 경로감 쇄가 상당하여 이러한 용량증가를 감당할 수 없을 것 이다. 따라서, 매크로 셀룰러 망 위에 스몰 셀 (예: 마 이크로 셀/ 피코 셀/ 펨토 셀)을 설치하여 기지국과 사 용자 사이의 경로감쇄를 줄이고, 결과적으로, 용량을 증가시킬 수 있는 이종 셀룰러 망 개념이 등장하였다 ${ }^{[2]}$.

이종 셀룰러 망의 경우, 매크로 셀은 상대적으로 넓 은 커버리지 영역을 지원해야 하므로 송신전력이 매 우 높다. 따라서, 대부분의 사용자들에게 스몰 셀 기 지국에 비해 매크로 셀 기지국에 의한 신호가 더 강하 게 수신될 것이므로, 가장 강한 신호가 수신되는 기지 국을 소속 기지국으로 선택한다면 대부분의 사용자들 이 매크로 셀을 소속 기지국으로 선택하게 되어 매크 로 셀과 스몰 셀 사이의 부하 불균형이 발생한다.

이러한 부하 불균형 문제를 해결하기 위해 매크로 셀에 소속된 사용자들을 스몰 셀에 소속되도록 소속 셀을 전환하고 이 때문에 발생하는 간섭문제를 완화 시키는 enhanced inter-cell interference coordination (eICIC) 기술이 도입되었다 ${ }^{[3]}$. eICIC 기술은 cell range expansion (CRE) 기법과 almost blank subframe (ABS) 기법으로 구성되며, 각 기법은 구체 적으로 다음과 같다. $\mathrm{CRE}$ 기법은 스몰 셀로부터 사용 자에게 수신되는 가장 강한 신호의 강도가 매크로 셀 로부터 수신되는 신호의 강도 보다 낮더라도, 두 신호 의 차이가 일정한 문턱치 값 이하일 경우 스몰 셀을 소속기지국으로 선택하는 기법이다. 즉, 스몰 셀의 커 버리지 영역을 강제로 확장하여 매크로 셀 기지국에 집중된 사용자들을 스몰 셀들로 분산되게 함으로써, 전체 시스템 부하의 균형을 이룰 수 있게 해주는 기법 이다. 그러나, $\mathrm{CRE}$ 기법을 통해 스몰 셀로 소속 셀을 전환한 사용자는 여전히 매크로 셀 기지국으로부터 수신되는 신호가 가장 강하기 때문에 signal to interference plus noise ratio (SINR) 성능이 저하되는 문제가 발생한다. $\mathrm{ABS}$ 기법은 이 문제를 해결하기 위 해 적용되는 기법이다. 이는 이종 셀룰러 망을 구성하 는 모든 셀의 프레임 구간을 $\mathrm{ABS}$ 구간과 non-ABS 구간으로 분할하고, non-ABS 구간동안은 매크로 셀 과 스몰 셀이 기존과 같이 동작하고, $\mathrm{ABS}$ 구간 동안 에는 매크로 셀은 동기화를 위한 최소한의 정보 외에 는 어떠한 신호도 전송하지 않도록 한다. 따라서,

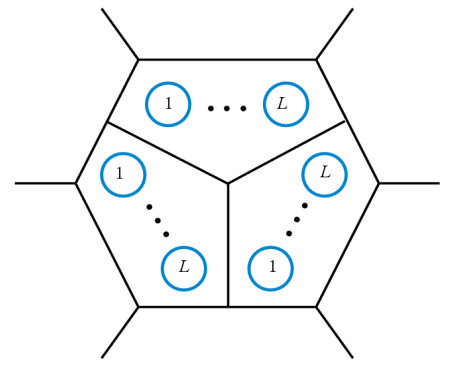

그림 1 이종 셀룰러 망 구조

Fig. 1. Illustration of heterogeneous cellular network structure.

$\mathrm{CRE}$ 를 통해 스몰 셀로 소속 셀을 전환한 사용자들에 게 $\mathrm{ABS}$ 구간의 무선 자원들만을 할당한다면 이러한 SINR 성능저하 문제를 해결할 수 있다.

이러한 $\mathrm{eICIC}$ 기술과 관련하여 최근 활발한 연구 가 진행되고 있다. 구체적으로 $\mathrm{eICIC}$ 기법에서 지원 하는 $\mathrm{ABS}$ 기술의 성능평가를 위한 수학적 모델링을 제시하여 이종 셀룰러 망 분석에 적용하였고 ${ }^{[4]}$, 이종 셀룰러 망 환경에서 간섭완화를 위한 전력제어와 $\mathrm{ABS}$ 기술을 혼합운용 함으로써 용량증대가 가능함을 보였다 ${ }^{[5]}$. 또한, 이종 셀룰러 망 전체의 사용자들의 효 용함수의 합을 최대화하는 최적의 $\mathrm{ABS}$ 구간비율을 결정하는 알고리즘이 제안되었으며 ${ }^{[6]}$, 전체 사용자 효 용함수 합을 최대화 할 수 있도록 최적의 $\mathrm{ABS}$ 구간 비율과 스몰 셀 기지국에서 $\mathrm{ABS}$ 구간의 자원을 할당 받는 사용자들을 결정하는 알고리즘이 제안되었다 ${ }^{[7,8]}$. 동적으로 이종 셀룰러 망의 상태가 변화할 때, 그에 따라 적응적으로 $\mathrm{ABS}$ 구간비율을 조정하면 시스템의 성능을 안정적으로 유지할 수 있음을 보였다 ${ }^{[9]}$. 또한, $\mathrm{CRE}$ 기법에 사용되는 문턱치 값과 $\mathrm{ABS}$ 구간비율에 따라 eICIC 성능이 어떻게 변화하는지 시뮬레이션 결 과를 통해 증명한 결과도 발표되었다 ${ }^{[3,10,11]}$. 최근에는 매크로 셀의 자원 사용율과 인접한 스몰 셀 기지국의 자원 사용율이 균형을 이루도록 $\mathrm{CRE}$ 문턱치를 적응 적으로 결정한 후, 사용자들의 효용함수의 합을 최대 화하는 최적의 $\mathrm{ABS}$ 구간을 결정하는 기법이 제안 되 었다 ${ }^{[12]}$.

그러나 기존의 연구에서는 사용자 부하의 분산을 $\mathrm{CRE}$ 문턱치 값만을 이용하여 수행하므로 셀 간 부하 불균형 문제를 해결하는 것에는 한계가 있다. 왜냐하 면, 스몰 셀로 소속 셀을 전환할 경우 수율 성능이 증 가될 것임에도 불구하고 $\mathrm{CRE}$ 를 통한 소속 기지국 전 환 조건을 만족하지 못해 소속 셀 전환을 할 수 없는 사용자들이 여전히 상당수 존재할 것으로 예상되기 때문이다. 따라서, 전체 사용자들의 비례공정 효용함 
수의 합을 최대화하는 최적의 사용자-소속 기지국 조 합과 $\mathrm{ABS}$ 구간비율을 찾을 수 있다면 기존 연구에서 의 성능 한계를 극복할 수 있을 것이다. 그러나, 발생 가능한 사용자의 소속 셀 전환 조합은 사용자 수와 셀 의 수에 따라 지수적으로 증가된다. 이와 같이 사용자소속기지국 조합과 $\mathrm{ABS}$ 구간비율을 조정하여 비례공 정 효용함수의 합을 최대화하는 문제는 전형적인 배 정문제로서 Non-deterministic Polynomial-time (NP) 난해로 알려져 있으며 이러한 문제에 대한 최적해를 구하는 것은 현실적으로 어렵다 ${ }^{[13]}$, 따라서, 본 논문에 서는 탐욕 알고리즘 기반의 사용자-소속기지국 전환 과정과 $\mathrm{ABS}$ 구간비율을 결정하는 과정을 재귀적으로 결합하여 비례공정 효용함수의 합을 증가시킬 수 있 는 준최적기법을 제안한다.

본 논문은 다음과 같이 구성된다. 프 장에서는 $\mathrm{eICIC}$ 기술과 시스템 모델에 대해 설명하고, III 장에 서는 제안하는 부하 분산 기법을 설명한다. $\mathrm{IV}$ 장에서 는 제안된 기법의 시스템 레벨 시뮬레이션 결과를 이 용하여 성능을 검증하고, 마지막으로 $\mathrm{V}$ 장에서 결론 을 맺는다.

\section{II. 시스템 모델}

\section{1 이종 셀룰러 망의 구조}

본 논문에서는 모든 기지국에서 동일한 무선 자원 을 사용하는 time division multiple access (TDMA) 기반의 이종 셀룰러 망을 고려한다. 그림 1 은 본 논문 에서 고려하는 이종 셀룰러 망의 구조를 나타낸다. 하 나의 매크로 셀은 3 개의 매크로 섹터 셀로 분할되며, 각 매크로 섹터 셀 영역에는 $L$ 개의 스몰 셀이 존재 한다고 가정한다. 또한, 모든 사용자들은 어떤 셀이라 도 자유롭게 접속이 가능한 open access 방식으로 운 영된다고 가정한다.

그림 2는 $\mathrm{ABS}$ 기법을 고려한 매크로 셀과 스몰 셀 의 프레임 구조를 나타낸다. 각 프레임은 non-ABS 구 간과 $\mathrm{ABS}$ 구간으로 분할되며, 전체 프레임에서 $\mathrm{ABS}$ 구간이 차지하는 비율을 $\mathrm{ABS}$ 구간비율 $\alpha(0<\alpha<1)$ 로 정의한다. 또한, 매크로 셀은 $\mathrm{ABS}$ 구간에서 어떠 한 신호도 전송하지 않고, 스몰 셀은 모든 프레임 구 간에서 신호를 전송한다고 가정한다.

이와 같은 프레임 구조에서, 임의의 매크로 셀에 소 속된 각 사용자는 non-ABS 구간의 자원만을 할당 받 는다고 가정하자. 그에 반해, 임의의 스몰 셀에 소속 된 각 사용자는 non-ABS 구간 혹은 $\mathrm{ABS}$ 구간 중 하 나를 선택해 해당 구간의 자원만을 할당 받는다고 가

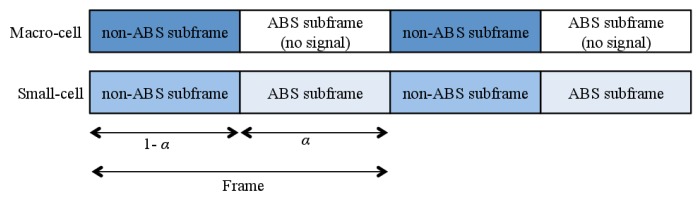

그림 2. $\mathrm{ABS}$ 기법을 적용한 프레임 구조

Fig. 2. Illustration of frame structure supporting ABS scheme.

정한다. 즉, non-ABS 구간의 자원을 지원하는 스몰 셀 혹은 $\mathrm{ABS}$ 구간의 자원만을 지원하는 스몰 셀에 소속된다는 의미이다. 기호의 단순성을 위해, 전체 기 지국들의 집합 $\mathcal{B}$ 는 매크로 셀 기지국들의 집합 $\mathcal{M}$, non-ABS 구간의 자원을 지원하는 스몰 셀 기지국들 의 집합 $\mathcal{S}$, 그리고 $\mathrm{ABS}$ 구간의 자원을 지원하는 스 몰 셀 기지국들의 집합 $\tilde{\mathcal{S}}$ 로 구성된다고 가정하자 (즉, $\mathcal{B}=\mathcal{M} \cup \mathcal{S} \cup \tilde{\mathcal{S}})$. 여기서, $\mathcal{S}$ 와 $\tilde{\mathcal{S}}$ 는 물리적으로는 동 일한 스몰 셀 기지국들로 구성되어 있으며 단지 non-ABS 구간의 자원을 사용하느냐 ABS 구간의 자 원을 사용하느냐에 따라 논리적으로 구분한다. 임의의 사용자의 특정 기지국 소속 여부를 나타내는 변수 $X_{i, k}$ 를 정의한다. 구체적으로 $X_{i, k}=1$ 일 경우, 사용 자 $k$ 가 기지국 $i$ 에 소속되어 있음을 $X_{i, k}=0$ 일 경우, 그렇지 않음을 나타낸다. 모든 사용자는 반드시 하나 의 기지국에만 소속되어 있다고 가정하자. 이는

$$
\sum_{i \in \mathcal{B}} X_{i, k}=1
$$

을 만족한다.

\section{2 수신신호 모델}

플랫 페이딩 채널 환경이라 가정하며, non-ABS 구 간과 $\mathrm{ABS}$ 구간의 슬롯 $q$ 에서 사용자 $k$ 가 수신하는 신호는 각각

$y_{k}(t)= \begin{cases}\sum_{i^{\prime} \in \mathcal{M} \cup \mathcal{S}} \sqrt{P_{i^{\prime}} G_{i^{\prime}, k}} h_{i^{\prime}, k}^{q} s_{i^{\prime}}(t)+n_{k}(t), & q \in \mathcal{Q}_{0} \\ \sum_{i^{\prime} \in \mathcal{\mathcal { S }}} \sqrt{P_{i^{\prime}} G_{i^{\prime}, k}} h_{i^{\prime}, k}^{q} s_{i^{\prime}}(t)+n_{k}(t), & q \in \mathcal{Q}_{1}\end{cases}$

이다. 여기서, $\mathcal{Q}_{0}$ 는 non-ABS 구간의 슬롯 자원 집합, $\mathcal{Q}_{1}$ 는 $\mathrm{ABS}$ 구간의 슬롯 자원 집합, $P_{i}$ 는 기지국 $i$ 의 송신전력, $s_{i}(t)$ 는 기지국 $i$ 의 송신신호, $G_{i, k}$ 는 기지 국 $i$ 와 사용자 $k$ 사이의 경로감쇄와 음영손실을 포함 하는 링크이득, $n_{k}(t)$ 는 평균 0 , 분산 $N_{0}$ 인 백색 복소 
가우시간 잡음, 그리고 $h_{i, k}^{q}$ 는 $q$ 번째 슬롯에서의 레일 리 페이딩 값이며, $E\left\{h_{i, j}^{q}\right\}=0, E\left\{h_{i, j}^{q}\left(h_{i^{\prime}, j^{\prime}}^{q^{\prime}}\right)^{*}\right\}=$ $\delta\left(q-q^{\prime}\right) \delta\left(i-i^{\prime}\right) \delta\left(k-k^{\prime}\right)$ 을 만족한다. CRE를 고려하여 사용자 $k$ 는 다음과 같은 과정을 거쳐 소속 셀을 결정 한다. 사용자 $k$ 는 우선 기지국 $\pi_{0}, \pi_{1}$ 를 찾는다. 여기 서, $\pi$ 는

$$
\lambda_{\pi_{0}, k} \geq \lambda_{\pi_{1}, k} \geq \cdots \geq \lambda_{\pi_{|\mathcal{M} \cup \mathcal{S}|, k}}
$$

를 만족하는 permutation 이다. 수식 (3)에서 $\lambda_{i, k}=P_{i} G_{i, k}$ 이며, $|\mathcal{M} \cup \mathcal{S}|$ 는 집합 $\mathcal{M} \cup \mathcal{S}$ 의 원소 의 개수이다. 이때, 다음 조건

$$
\pi_{0} \in \mathcal{M}, \pi_{1} \in \mathcal{S}, \frac{\lambda_{\pi_{0}, k}}{\lambda_{\pi_{1}, k}} \leq \Gamma
$$

을 만족하지 못하는 경우, 사용자 $k$ 는 매크로 기지국 $\pi_{0}$ 를 소속 기지국으로 선택하고, 해당 셀의 non-ABS 구간의 슬롯 자원을 할당 받는다. 여기서, $\Gamma$ 는 $\mathrm{CRE}$ 결정을 위한 문턱치 이다. 따라서, non-ABS 구간의 슬롯 자원을 할당 받는 사용자 $k$ 의 수신신호의 SINR 은

$$
\gamma_{i, k}^{q}=\left|h_{i, k}^{q}\right|^{2} \bar{\gamma}_{i, k}, i \in \mathcal{M} \cup \mathcal{S}
$$

이다. 여기서, $\bar{\gamma}_{i, k}$ 는 평균 SINR 이며

$$
\bar{\gamma}_{i, k}=\frac{P_{i} G_{i, k}}{\sum_{i^{\prime} \in \mathcal{M} \cup \mathcal{S}, i^{\prime} \neq i} P_{i^{\prime}} G_{i^{\prime}, k}+N_{0}}
$$

로 표현된다. 그에 반해, 조건 (4)를 만족하는 경우, 사 용자 $k$ 는 스몰 셀 기지국 $\pi_{1}$ 의 $\mathrm{ABS}$ 구간의 슬롯 자 원을 할당 받는다. 이때, 2.1 절에서 설명한 바와 같이, 사용자 $k$ 가 소속된 기지국은 $\pi_{1}$ 와 물리적으로 동일하 지만 $\mathrm{ABS}$ 구간의 슬롯 자원만을 사용하는 논리적으 로 구분되는 기지국이다. 따라서, 해당 수신신호의 SINR은

$$
\gamma_{i, k}^{q}=\left|h_{i, k}^{q}\right|^{2} \bar{\gamma}_{i, k}, i \in \tilde{\mathcal{S}}
$$

이다. 여기서, $\bar{\gamma}_{i, k}$ 는 평균 SINR 이며

$$
\bar{\gamma}_{i, k}=\frac{P_{i} G_{i, k}}{\sum_{i^{\prime} \in \overline{\mathcal{S}}, i^{\prime} \neq i} P_{i^{\prime}} G_{i^{\prime}, k}+N_{0}}
$$

이다. 또한, $\pi_{0}, \pi_{1} \in \mathcal{M}$ 혹은 $\pi_{0} \in \mathcal{S}$ 인 경우에는 $\pi_{0}$ 를 소속 기지국으로 선택하고, 해당 기지국의 non-ABS 자원을 할당한다.

기지국 $i$ 는 non-ABS 혹은 $\mathrm{ABS}$ 구간의 슬롯 $q$ 에 서 자신에게 소속된 사용자들 중 다음을 만족하는

$$
k^{*}=\underset{k \in\left\{k^{\prime} \mid X_{i, k^{\prime}}=1\right\}}{\arg \max } \frac{\gamma_{i, k}^{q}}{\bar{\gamma}_{i, k}}
$$

사용자 $k^{*}$ 를 선택하여 슬롯 $q$ 를 할당한다. 즉, 소속 사용자들 중 슬롯 $q$ 에서의 SINR과 평균 SINR의 비 가 가장 큰 사용자에게 해당 슬롯을 할당한다. 각 사 용자의 SINR을 평균 SINR로 나누어준 확률변수 $\gamma_{i, k}^{q} / \bar{\gamma}_{i, k}$ 는 지수확률변수이므로 ${ }^{[14]}$, 이 스케쥴링 과정 은 기지국 $i$ 에 속한 사용자 수 $N_{i} \quad\left(=\sum_{k \in \mathcal{U}} X_{i, k}\right)$ 개의 지수확률변수들 중 가장 큰 확률변수를 선택하는 과 정과 동일하다. 여기서, $\mathcal{U}$ 는 모든 사용자들의 집합이 다. 따라서, $\mathrm{ABS}$ 구간비율 $\alpha$ 가 주어졌을 때, 기지국 $i$ 에 소속된 사용자 $k$ 의 평균 수율 $T_{i, k}\left(\alpha, N_{i}\right)$ 는

$$
T_{i, k}\left(\alpha, N_{i}\right)=C_{i}(\alpha) \int_{0}^{\infty} \log _{2}\left(1+x \bar{\gamma}_{i, k}\right) e^{-x}\left(1-e^{-x}\right)^{N_{i}-1} d x
$$

이다 ${ }^{[14]}$. 여기서, $e^{-x}\left(1-e^{-x}\right)^{N_{i}-1}$ 는 $N_{i}$ 개의 지수확 률변수들 중 가장 큰 확률변수에 대한 확률밀도함수 이며, $C_{i}(\alpha)$ 는 $\mathrm{ABS}$ 구간비율 $\alpha$ 에 따른 non-ABS 및 $\mathrm{ABS}$ 구간의 실질 시스템 대역폭으로서

$$
C_{i}(\alpha)= \begin{cases}(1-\alpha), & i \in \mathcal{M} \cup \mathcal{S} \\ \alpha, & i \in \tilde{\mathcal{S}}\end{cases}
$$

이다. 따라서, 수식 (1)을 고려하면 주어진 ABS 구간 비율 $\alpha$ 에 대해 기지국 $i$ 에 소속된 사용자 $k$ 의 수율은

$$
R_{k}(\alpha)=\sum_{i \in \mathcal{B}} X_{i, k} T_{i, k}\left(\alpha, N_{i}\right)
$$

이 된다. 


\section{III. 제안하는 부하 분산 기법}

\section{1 부하 분산 기법 알고리즘}

서론에서 언급한 바와 같이 이종 셀룰러 망에 $\mathrm{eICIC}$ 기술을 도입하여, 매크로 셀에 밀집된 사용자 들을 스몰 셀로 분산시켜 기존의 매크로 셀룰러 망에 비해, 전체 사용자 수율 성능을 향상시킬 수 있게 되 었다. 그러나, $\mathrm{CRE}$ 를 이용하여 소속 기지국을 결정하 므로 여전히 매우 낮은 수율 성능의 사용자들이 존재 할 수 있다. 따라서, 본 논문에서는 사용자들의 소속 기지국 $\left\{X_{i, k}^{*}\right\}$ 과 $\mathrm{ABS}$ 구간비율 $\alpha$ 를 조정하여 사용 자들의 효용함수 합을 최대화 하는 다음과 같은 문제

$$
\left\{\left\{X_{i, k}^{*}\right\}, \alpha^{*}\right\}=\underset{\left\{X_{i, k}\right\}, 0<\alpha<1}{\arg \max } \sum_{k \in \mathcal{U}} U_{k}\left(R_{k}(\alpha)\right)
$$

를 고려한다. 여기서, $U_{k}(\cdot)$ 는 사용자 $k$ 의 효용함수이 다. 효용함수는 목적에 따라 여러 가지 형태를 가질 수 있다. 예를 들면 시스템 수율 즉, 전체 사용자 수율 의 합 $\sum_{k \in \mathcal{U}} R_{k}(\alpha)$ 을 최대화하는 경우, 해당 효용함 수는 $U_{k}(R)=R$ 이 된다. 이 경우, 각 기지국에서 수 율이 가장 높은 사용자들에게 모든 자원을 할당한다 면 전체 사용자 수율의 합을 최대화 할 수 있을 것이 다. 그러나, 이 경우에는 시스템 수율을 최대화할 수 있어도 사용자들 간의 공평성은 만족 시켜줄 수 없다. 따라서, 본 논문에서는 시스템 수율과 사용자들 간의 공평성의 균형을 유지하기 위해 비례공정 효용함수 $U_{k}(R)=\log R$ 를 적용하여 비례공정 효용함수의 합 (즉, 사용자 수율의 로그의 합) $\sum_{k \in \mathcal{U}} \log R_{k}(\alpha)$ 을 최 대화하는 최적화 문제를 고려한다 ${ }^{[15]}$.

이 문제의 최적해를 구하기 위해서는 발생 가능한 모든 $\left\{X_{i, k}\right\}$ 와 $\alpha$ 에 대해 비례공정 효용함수의 합 $\sum_{k \in \mathcal{U}} \log R_{k}(\alpha)$ 를 계산해야 한다. 그러나, 주어진 $\alpha$ 에 대해 발생 가능한 모든 $\left\{X_{i, k}\right\}$ 조합의 개수는 $|\mathcal{B}|^{\mid \mathcal{U}}$ 이므로 사용자 수와 기지국의 수가 증가하는 경 우 지수적으로 조합의 개수가 증가된다. 이러한 문제 는 전형적인 배정문제로서 NP 난해 문제로 알려져 있 으며 ${ }^{[13]}$, 이 문제에 대한 최적해를 구하는 것은 현실적 으로 어렵다. 따라서, 본 논문에서는 준최적해를 구하 는 부하 분산 기법을 제안한다. 구체적으로 각 기지국 에서 탐욕 알고리즘 기반의 소속 기지국 전환 과정 (즉, 각 기지국의 소속 사용자들 가운데 소속 기지국 전환 시 가장 높은 비례공정 효용함수 합이 증가가 예
상되는 사용자를 선택하여 소속 기지국을 전환한다.) 과 비례공정 효용함수 합을 최대화하는 $\mathrm{ABS}$ 구간비 율 $\alpha$ 를 결정하는 과정을 재귀적으로 결합하여 준최적 해를 찾는다.

제안하는 기법의 동작은 다음과 같다. 먼저, 임의의 사용자 $k$ 가 전환 가능한 기지국들의 집합을 $\mathcal{C}_{k}$ 라 정 의한다. 구체적으로 $\mathcal{C}_{k}$ 는 사용자 $k$ 에 대해 하향링크 수신신호의 SINR이 $\gamma_{t h}$ 보다 큰 기지국들의 집합으로 서

$$
\mathcal{C}_{k}=\left\{i \mid \bar{\gamma}_{i, k} \geq \gamma_{t h}\right\}
$$

로 정의한다. 이와 같이 생성된 $\left\{\mathcal{C}_{k}\right\}$ 를 바탕으로 $\left.\mathrm{i}\right)$ 사용자의 소속 기지국 전환, ii) $\mathrm{ABS}$ 구간비율 갱신 으로 구성된 부하 분산 기법을 실행한다.

사용자의 소속 기지국 전환 : 주어진 $\mathrm{ABS}$ 구간비 율 $\alpha$ 에 대해, 기지국 $i$ 에 소속된 각 사용자 $k$ 는 $M$ 프레임 주기로 다음 과정을 수행한다. $\mathcal{C}_{k}$ 에 속한 기지 국들 중에서

$$
i_{k}^{*}=\underset{i^{\prime} \in \mathcal{C}_{k} \backslash\{i\}}{\arg \max } \Delta_{i, i^{\prime}}^{k}
$$

를 만족하는 기지국 $i_{k}^{*}$ 를 찾는다. 여기서, $\Delta_{i, i}^{k}$ 는 기 지국 $i$ 가 사용자 이동 과정을 수행하기 전과 수행 후 의 로그 수율 합의 차로서

$$
\begin{array}{r}
\Delta_{i, i^{\prime}}^{k}=\left[\sum_{k^{\prime} \in\left\{k^{\prime \prime} \mid X_{i, k^{\prime \prime}}=1\right\} \backslash\{k\}} \log T_{i, k^{\prime}}\left(\alpha, N_{i}-1\right)\right. \\
+\sum_{k^{\prime} \in\left\{k^{\prime \prime} \mid X_{i^{\prime}, k^{\prime \prime}}=1\right\} \cup\{k\}} \log T_{i^{\prime}, k^{\prime}}\left(\alpha, N_{i^{\prime}}+1\right) \\
-\sum_{k^{\prime} \in\left\{k^{\prime \prime} \mid X_{i, k^{\prime \prime}}=1\right\}} \log T_{i, k^{\prime}}\left(\alpha, N_{i}\right) \\
\left.-\sum_{k^{\prime} \in\left\{k^{\prime \prime} \mid X_{i^{\prime}, k^{\prime \prime}}=1\right\}} \log T_{i^{\prime}, k^{\prime}}\left(\alpha, N_{i^{\prime}}\right)\right]
\end{array}
$$

이다. 기지국 $i$ 에 소속된 모든 사용자들에 대하여 $\left\{i_{k}^{*}\right\}$ 가 구해지면, 이들 중에서 가장 높은 수율 증가가 예측되는 사용자 $k^{\S}$ 를 찾는다. 즉, 사용자 $k^{\S}$ 는

$$
k^{\S}=\underset{k \in\left\{k^{\prime} \mid X_{i, k^{\prime}}=1\right\}}{\arg \max } \Delta_{k, i_{k}^{*}}^{k}
$$


를 만족한다. 이때, $\Delta_{i, i_{k \S}^{*}}^{k^{\S}}>0$ 이면, $X_{i, k \S}$ 와 $X_{i_{k \S}^{*}, k^{\S}}$ 를

$$
X_{i, k^{\S}}=0, X_{i_{k \S}^{*}, k^{\S}}=1
$$

와 같이 갱신한다. $M$ 프레임이 경과하면 각 기지국에 서 사용자 이동 과정이 1 회 완료되며, 이러한 과정을 각 기지국에서 $Q$ 회 실행한다. 해당 과정이 완료되면 아래에 설명하는 $\mathrm{ABS}$ 구간비율 갱신 과정을 실행한 다.

ABS 구간비율 갱신 : $(Q \times M)$ 프레임이 경과하 여 모든 기지국에서 사용자 이동 과정이 $Q$ 회 실행되 면, 다음을 만족하는

$$
\alpha^{*}=\underset{0<\alpha^{\prime}<1}{\arg \max } \sum_{k \in \mathcal{U}} \log R_{k}\left(\alpha^{\prime}\right)
$$

$\alpha^{*}$ 를 찾고 $\mathrm{ABS}$ 구간비율 $\alpha$ 를 $\alpha$ 로 갱신한다. 갱신된 $\mathrm{ABS}$ 구간비율을 적용한 상태에서 다시 사용자의 소 속 기지국 전환을 수행한다. 이와 같은 과정을 비례공 정 효용함수의 합 $\sum_{k \in \mathcal{U}} \log R_{k}(\alpha)$ 의 증가 값이 $\epsilon$ 이 하일 때까지 반복한다. 여기서, $\epsilon$ 는 수렴여부를 판단 하는 매개변수로서 매우 작은 값으로 설정한다.

그림 3은 제안된 알고리즘의 흐름도를 보여준다. $\tilde{R}$ 은 전체 알고리즘이 반복 될 때마다 갱신되는 $\sum_{k \in \mathcal{U}} \log R_{k}\left(\alpha^{*}\right)$ 값을 저장하기 위한 변수이며, $C_{i}$ 는 각 기지국 $i$ 의 사용자 이동 횟수를 저장하기 위한 변 수이다. 알고리즘이 시작되면 $\tilde{R}$ 값은 $-\infty$, 모든 기지 국 각각에 대한 변수 $C_{i}$ 는 0 으로 초기화 한다. 다음으 로, 특정 프레임에서 기지국 $i$ 에 소속된 각 사용자 $k$ 에 대해 수식 (14)를 만족하는 기지국 $i_{k}^{*}$ (즉, 사용자 $k$ 가 소속 기지국을 이동할 때 가장 높은 수율 증가가 예상되는 기지국)을 찾는다. 이후 기지국 $i$ 에 소속된 사용자 가운데 수식 (16)을 만족하는 사용자 $k^{\S}$ (즉, 소속 셀 전환 시 예상 효용함수 합의 수율 증가 값이 가장 높은 사용자)를 찾고, $\Delta_{i,{ }_{k}^{\natural}}^{k^{\S}}>0$ 의 조건을 만족 할 경우 수식 (17)과 같이 사용자 $k^{\S}$ 의 소속 기지국을 $i_{k \S}$ 로 전환 시키고 $C_{i}$ 값을 1 증가시킨다. 반대로 해 당 조건을 만족하지 못할 경우 기지국 $i$ 의 사용자 이 동은 일어나지 않고 $C_{i}$ 값만 1 을 증가시킨다. 이 과정 을 모든 기지국들의 $C_{i}$ 값이 $Q$ 가 될 때까지 $M$ 프레 임을 주기로 반복된다. 이 과정이 완료되면 전체 사용

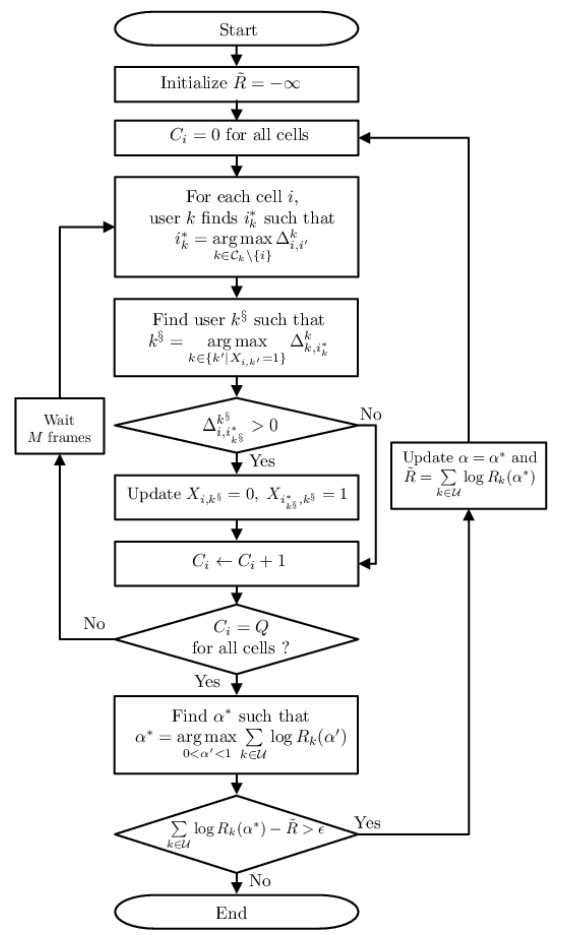

그림 3. 제안 기법 흐름도

Fig. 3. Flow chart of the proposed scheme.

자의 로그 사용자 수율 합 $\sum_{k \in \mathcal{U}} \log R_{k}\left(\alpha^{\prime}\right)$ 을 최대화 하는 $\alpha^{*}$ 를 찾고, $\sum_{k \in \mathcal{U}} \log R_{k}\left(\alpha^{*}\right)$ 과 $\tilde{R}$ 을 비교한다. $\sum_{k \in \mathcal{U}} \log R_{k}\left(\alpha^{*}\right)-\tilde{R}>\epsilon$ 의 조건을 만족할 경우, $\alpha$ 와 $\tilde{R}$ 을 각각 $\alpha^{*}$ 와 $\sum_{k \in \mathcal{U}} \log R_{k}\left(\alpha^{*}\right)$ 로 갱신하고 $C_{i}$ 를 0 으 로 초기화한 후에 다시 사용자 이동 과정을 수행한다. 이에 반해 해당 조건을 만족하지 않는다면 $\sum_{k \in \mathcal{U}} \log R_{k}\left(\alpha^{*}\right)$ 값이 수렴했다고 판단하고 알고리 즘을 종료하게 된다.

\section{2 동작예제}

제안된 알고리즘의 동작을 설명하기 위해 기지국 0 과 1 로 구성된 시스템을 고려하자. 또한, 전체 사용자 수 7명 중에 사용자 0 4는 기지국 0에 소속되어있고, 사용자 5 와 6 은 기지국 1 에 소속되었다고 가정하자. 표 1(a) (c)는 기지국 0에 소속된 사용자들 가운데 소 속 셀 전환 시 가장 높은 수율 증가가 예측되는 사용 자의 소속 기지국을 기지국 1 로 전환하는 과정을 나 타낸다. 먼저 표 1(a)는 $\mathrm{ABS}$ 구간비율 $\alpha$ 가 주어졌을 때 기지국 0에 소속된 전체 사용자 수율 값 및 사용자 전환을 수행하기 위해 필요한 사용자 수율 예측 값들 을 나타낸다. 구체적으로 두 번째 열부터 다섯 번째 
표 1. 제안 기법 동작 예제

Table 1. Operation example of the proposed scheme.

(a) User throughput at cell 0 before the user association update.

\begin{tabular}{|c|c|c|c|c|}
\hline \multirow{2}{*}{ User| } & \multicolumn{5}{|c|}{ User throughput at cell 0 } \\
\cline { 2 - 6 } & $\begin{array}{c}\text { Presen } \\
\mathrm{t}\end{array}$ & $\begin{array}{c}\text { Other user is } \\
\text { associated with cell 1 } 1\end{array}$ & $\begin{array}{c}\text { Correspondoing user is } \\
\text { associated with cell } 1\end{array}$ & $\Delta_{0,1}^{k}$ \\
\hline 0 & 7 & 7.6 & 7.2 & 1.0433 \\
\hline 1 & 5 & 6 & 4.4 & 0.7872 \\
\hline 2 & 10 & 10.4 & 9.5 & 1.0069 \\
\hline 3 & 3 & 3.8 & 3.7 & 1.0707 \\
\hline 4 & 0.5 & 1 & 1.5 & 1.5028 \\
\hline
\end{tabular}

(b) User throughput at cell 1 before the user association update.

\begin{tabular}{|c|c|c|}
\hline \multirow{2}{*}{ User } & \multicolumn{2}{|c|}{ User throughput at cell 1 } \\
\cline { 2 - 3 } & Present & $\begin{array}{l}\text { Other user in cell } 0 \text { is } \\
\text { associated with cell }\end{array}$ \\
\hline 5 & 7 & 6.5 \\
\hline 6 & 5 & 4.7 \\
\hline
\end{tabular}

(c) User throughput and associated cell after the user association update.

\begin{tabular}{|c|c|c|}
\hline User & Associated cell & User throughput \\
\hline 0 & 0 & 7.6 \\
\hline 1 & 0 & 6 \\
\hline 2 & 0 & 10.4 \\
\hline 3 & 0 & 3.8 \\
\hline 4 & 1 & 1.5 \\
\hline 5 & 1 & 6.5 \\
\hline 6 & 1 & 4.7 \\
\hline
\end{tabular}

열들은 각각 현재 사용자 수율, 자신이 아닌 다른 사 용자 1 명이 기지국 1 로 소속 기지국을 전환하였을 때 예측되는 자신의 수율, 자기 자신이 기지국 1 로 소속 기지국을 전환하였을 때 예측되는 자신의 수율, 그리 고 그 경우에 해당되는 수식 (15)의 $\Delta_{0,1}^{k}$ 값을 나타낸 다. 표 1(b)는 기지국 1 에 소속된 전체 사용자의 수율 및 기지국 0 에 소속된 사용자가 기지국 1 로 소속 기지 국을 전환 하였을 경우 예측 되는 사용자 수율 값들을 나타낸다. 구체적으로 두 번째 열은 현재 자신의 수율, 세 번째 열은 기지국 0 으로부터 사용자 1 명이 기지국 1 로 이동해 왔을 경우의 자신의 수율을 나타낸다. 하 나의 예로, 사용자 0 이 기지국 1 로 소속 셀을 전환하 는 경우를 고려하자. 표 1(a)로부터 사용자 0 은 7.2의 수율 값을 가질 것으로 예상할 수 있으며, 기지국 0에 소속된 나머지 사용자 1 4들은 사용자 수가 한명 감 소됨으로 인해 현재 수율 값들보다 약간 증가된 수율 값들을 가질 것으로 예측할 수 있다. 또한, 표 1(b)로 부터 기지국 1 에 소속된 사용자 5,6 들은 사용자 수가 한 명 증가됨으로 인해 기존의 수율 값들보다 약간 감
소된 수율 값들을 가질 것으로 예상할 수 있다.

표 1(a)를 이용하여, 특정 사용자 이동이 수행되기 전과 후의 기지국 0 과 1 의 전체 사용자 수율의 로그의 합을 비교하여 각 사용자에 대해 수식 (15)의 $\Delta_{0,1}^{0}$ 값 을 계산 한다. 예를 들어, 사용자 0 의 $\Delta_{0,1}^{0}$ 값은

$$
\begin{aligned}
\Delta_{0,1}^{0}= & (\log 6+\log 10.4+\log 3.8+\log 1) \\
& +(\log 6.5+\log 4.7+\log 7.2) \\
& -(\log 7+\log 5+\log 10+\log 3+\log 0.5) \\
& -(\log 7+\log 5) \\
= & 1.0433
\end{aligned}
$$

이다. 이와 관련하여 기지국 0에 소속된 사용자들의 $\Delta_{0,1}^{k}$ 값들을 표 1(a)의 마지막 열에 나타내었다. 이로 부터 가장 높은 수율 증가가 예상되는 사용자는 $\Delta_{0,1}^{k}$ 값이 가장 큰 사용자 4 임을 알 수 있다. 따라서, 사용 자 4 를 기지국 1 로 소속 셀을 전환 시키면 소속 셀 정 보와 수율 정보는 표 1(c)와 같이 갱신된다. 여기서, 기지국 0에 소속된 사용자 0 3들의 수율은 기지국 0 의 소속 사용자가 1 명 감소하였으므로 표 1(a)의 세 번째 열에 해당되는 수율 값을 갖게 되고, 기지국 1 에 소속된 사용자 5,6 은 사용자가 1 명 증가하였으므로 표 1(b)의 세 번째 열에 해당되는 수율 값을 갖게 된 다. 또한, 소속 기지국을 기지국 1 로 이동한 사용자 4 는 표 1(a)의 네 번째 열에 해당하는 수율 값을 갖게 된다. 이와 같은 과정을 모든 기지국에 대해 사용자 이동 과정을 $Q$ 회 수행한다. 이러한 과정이 완료되면 전체 사용자의 수율 정보를 이용하여, 로그 사용자 수 율 합이 최대가 되는 새로운 $\alpha^{*}$ 를 찾아 이를 $\alpha=\alpha^{*}$ 로 갱신하며, 갱신된 $\alpha$ 를 이용하여 다시 사용자 소속 기지국 전환을 수행한다.

\section{IV. 시스템 레벨 시뮬레이션}

\section{1 시뮬레이션 환경}

본 논문에서 제안하는 기법의 성능을 검증하기 위 해 매크로 셀과 스몰 셀로 구성되는 이종 셀룰러 망에 대한 시스템 레벨 시뮬레이션을 수행하였다. 제안하는 기법의 성능을 평가하기 위해 여러 가지 시스템 모델 들을 적용할 수 있으나, 본 논문에서는 $3 \mathrm{GPP}$ 에서 이 종 셀룰러 망에 적용할 기술들의 성능을 평가하기 위 한 목적으로 도입한 모델을 참고하여 시스템 모델을 구성하였다 ${ }^{[16]}$. 본 논문에서 사용한 시스템 모델이 여 러 실질적인 상황들을 반영한 일반적인 시스템 모델 


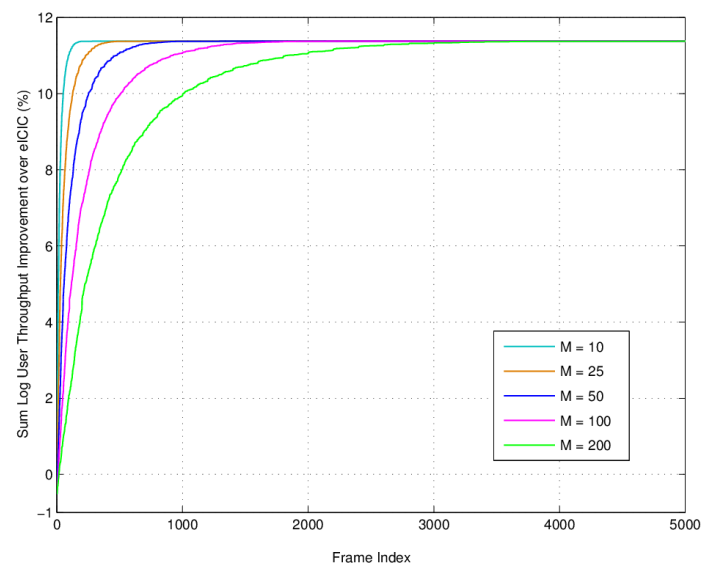

그림 4. $\mathrm{eICIC}$ 기법 $(\mathrm{CRE}=15 \mathrm{~dB})$ 대비 제안 기법 $(Q=1)$ 의 로그 사용자 수율 합 향상율의 수렴도

Fig. 4. Convergence of sum log user throughput improvement of the proposed scheme with $Q=1$ over eICIC with $\mathrm{CRE}=15 \mathrm{~dB}$.

이라고는 할 수 없지만 기존 기법의 성능을 비교, 평 가하기 위한 목적으로 사용하였다.

전체 시스템에는 19 개의 육각형 구조의 매크로 셀 들이 존재하며, 각 매크로 셀은 3 섹터 영역으로 분할 된다. 즉, 총 57개의 매크로 셀 섹터가 존재한다. 별도 의 언급이 없는 한 각각의 매크로 셀 섹터 영역 내에 $L=4$ 개의 스몰 셀이 임의의 위치에 분포 한다고 가 정한다. 여기서, 매크로 셀 간 거리는 $500 \mathrm{~m}$, 매크로 셀과 스몰 셀 간 최소 거리는 $75 \mathrm{~m}$,각 스몰 셀 간 최소 거리는 $40 \mathrm{~m}$ 이다. 각 매크로 셀 섹터 영역에 설치된 각 스몰 셀에는 매크로 셀 섹터 영역에 존재하는 전체 사용자들 중 4 명의 사용자들이 해당 스몰 셀의 반경 $40 \mathrm{~m}$ 이내의 거리에 균일하게 분포한다. 또한, 매크로 셀과 사용자 간 최소 거리와, 스몰 셀과 사용자 간 최 소 거리는 각각 $35 \mathrm{~m}, 10 \mathrm{~m}$ 이다.

일반적으로, 이종 망에서는 스몰 셀의 전송 전력이 증가할수록 해당 스몰 셀의 하위 백분위 사용자 수율 이 증가하는 경향이 있는 것으로 알려져 있다 ${ }^{[17]}$. 하지 만 스몰 셀의 전송 전력을 매크로 셀의 전송 전력 수 준까지 증가시킨다면 매크로 셀과 스몰 셀 사이에 극 심한 간섭이 발생하여 오히려 이종 망의 전체 수율 성 능이 저하된다 ${ }^{[18]}$. 따라서, 스몰 셀은 일반적으로 매크 로 셀보다 낮은 전송 전력을 사용해야 한다. 구체적으 로 본 논문에서는 $3 \mathrm{GPP}$ 에서 이종 셀룰러 망에 적용 할 기술들의 성능을 평가하기 위한 목적으로 도입한 모델을 참고하여 매크로 셀과 스몰 셀의 전송 전력을 각각 $46 \mathrm{dBm}, 37 \mathrm{dBm}$ 으로 적용하여 $9 \mathrm{~dB}$ 의 전송전력 차이가 나도록 설정하였다 ${ }^{[16]}$. 또한, 매크로 섹터 셀은

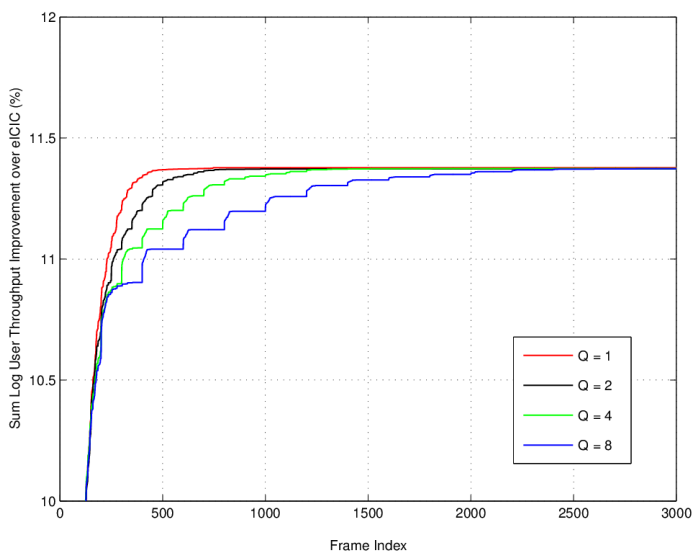

그림 5. $\mathrm{eICIC}$ 기법 $(\mathrm{CRE}=15 \mathrm{~dB})$ 대비 제안 기법 $(M=25)$ 의 로그 사용자 수율 합 향상율의 수렴도

Fig. 5. Convergence of sum log user throughput improvement of the proposed scheme with $M=25$ over eICIC with $\mathrm{CRE}=15 \mathrm{~dB}$.

표 2. 수렴하기 위해 소요되는 $\mathrm{ABS}$ 구간비율 갱신 횟수 및 프레임 수

Table 2. Summary of numbers of frames and ABS rate updates to converge.

\begin{tabular}{|c|c|c|c|c|}
\hline$Q$ & 1 & 2 & 4 & 8 \\
\hline $\begin{array}{c}\text { No. of frames } \\
\text { to } \\
\text { converge }\end{array}$ & 750 & 1080 & 1720 & 3220 \\
\hline $\begin{array}{c}\text { No. of ABS } \\
\text { rate updates to } \\
\text { converge }\end{array}$ & 30 & 21 & 18 & 17 \\
\hline
\end{tabular}

수평 방사각 $70^{\circ}$, 수직 방사각 $10^{\circ}$, 하향 경사각 $15^{\circ}$, 높이 $32 \mathrm{~m}, 18 \mathrm{dBi}$ 이득 값을 가지는 방향성 안테나를 사용하며, 스몰 셀은 $5 \mathrm{dBi}$ 의 이득 값을 가지는 전 방 향성안테나를 사용한다. 사용자의 경우, 안테나 높이 는 $1.5 \mathrm{~m}$ 이며, $0 \mathrm{dBi}$ 의 이득 값을 가지는 전방향성 안 테나를 사용한다.

모든 셀은 주파수 재사용률 1 , 프레임 길이 $10 \mathrm{msec}$, 유효대역폭 $9 \mathrm{MHz}$ 인 orthogonal frequency division multiple access (OFDMA) 를 사용한다. $180 \mathrm{kHz}$ 대역폭의 physical resource block (PRB) 단 위로 자원을 할당하며 ${ }^{[19]}$, 각 PRB 별로 독립적인 스 케쥴러를 적용한다고 가정한다. 또한, 각 $\mathrm{PRB}$ 를 구성 하는 모든 부반송파는 동일한 플랫 페이딩을 겪고, $\mathrm{PRB}$ 별로 통계적으로 독립적인 페이딩을 겪는다고 가정한다 ${ }^{[20]}$. 백색잡음 밀도는 $-173 \mathrm{dBm} / \mathrm{Hz}$ 이며, 잡 음 지수는 $7 \mathrm{~dB}$ 이라 가정한다. 또한, 사용자들의 소속 기지국 전환이 가능한 기지국들을 구성하기 위한 문 턱치 $\gamma_{t h}$ 는 $0 \mathrm{~dB}$ 를 적용한다.

기지국과 사용자 사이의 거리가 $d$ (킬로미터)일 


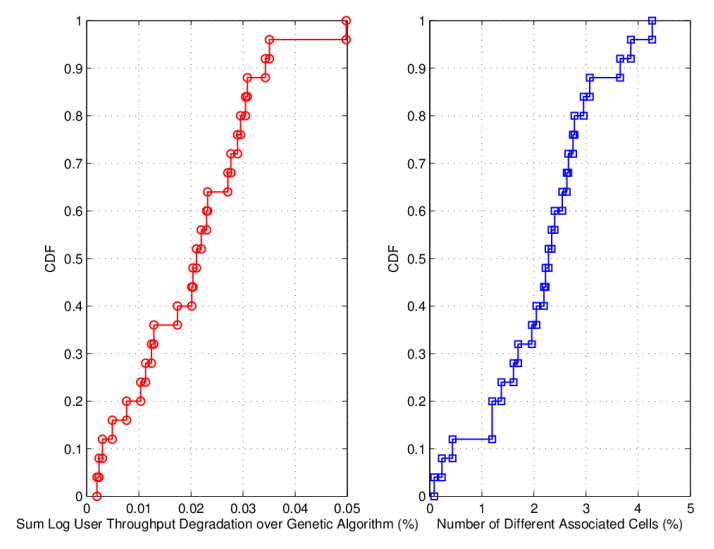

그림 6. 유전자 알고리즘 대비 제안 기법 $(M=25, Q=1)$ 의 로그 사용자 수율 합 감소율 및 사용자-소속 기지국 변화 율의 누적확률분포 함수

Fig. 6. Empirical cumulative distribution functions of sum $\log$ user throughput degradation over genetic algorithm and number of different associated cells $(M=25, Q=1)$

때, 매크로 셀 기지국과 사용자 사이, 스몰 셀 기지국 과 사용자 사이의 경로 감쇄 모델은 각각 $P L_{m}(d)=128.1+37.6 \log _{10}(d)(\mathrm{dB})$ 과

$P L_{s}(d)=140.7+36.7 \log _{10}(d) \quad(\mathrm{dB})$ 을 적용한다. 각 셀 사이의 음영 상관 값은 0.5 이며, 이때 각 매크로 셀을 구성하는 3 개의 매크로 섹터 셀들의 음영 상관 값은 1 이라 가정 한다.

성능 측정을 위해 독립적으로 발생시킨 100 개의 스 몰 셀 및 사용자 분포들에 대한 성능을 평균 하였다. 여기서, 각 분포는 57 개의 매크로 섹터 셀, 228 개의 스몰 셀, 3420 명의 사용자로 구성된다. 제안 기법과의 공정한 성능비교를 위해 $\mathrm{eICIC}$ 기법은 주어진 $\mathrm{CRE}$ 문턱치 값을 기준으로 사용자-소속 기지국을 결정한 후, 로그 사용자 수율 합 (즉, 비례공정 효용함수 합) 을 최대화 하는 $\mathrm{ABS}$ 구간비율을 결정하여 적용 하였 다 ${ }^{[6,9]}$.

\section{2 제안 기법의 수렴 특성}

그림 4는 임의의 스몰 셀 및 사용자 분포에서eICIC 기법 $(\mathrm{CRE}=15 \mathrm{~dB})$ 의 로그 사용자 수율 합 (즉, 비례 공정 효용함수의 합) 대비 제안 기법 $(Q=1)$ 의 로그 사용자 수율 합의 향상율을 보여준다. 구체적으로, 첫 번째 프레임에서 $\mathrm{eICIC}$ 기법(CRE $=15 \mathrm{~dB}, \alpha=0.5)$ 를 적용한 이후, 제안 기법을 적용하여 시간에 따른 로그 사용자 수율 합의 향상율을 보였다. 각 기지국의 사용 자 전환 실행 주기 $M$ 값에 관계없이 로그 수율 합이 일정한 값에 수렴하지만, $M$ 이 감소할수록 빠르게 수 렴함을 알 수 있다.

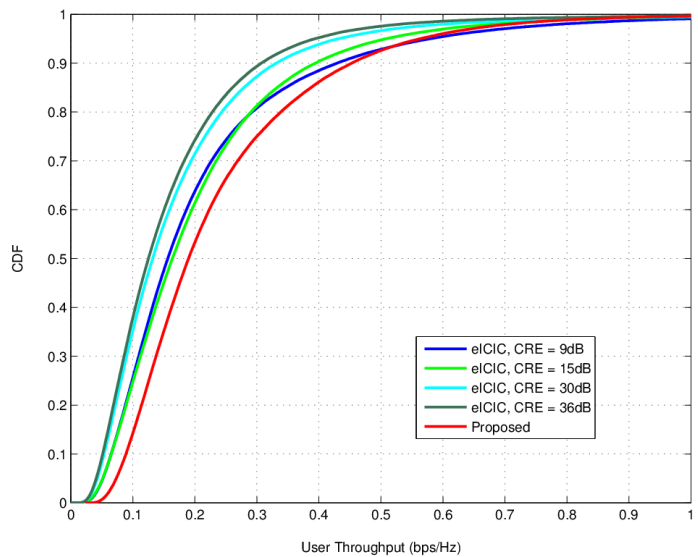

그림 7. 사용자 수율의 누적확률분포 함수 $(M=25, Q=1)$ Fig. 7. Empirical cumulative distribution function of user throughput $(M=25, Q=1)$

그림 5 는 그림 4 와 동일한 조건에서 $M=25$ 일 때, $Q$ 값에 따른 수렴 속도의 차이를 나타낸다. $Q$ 값 이 작을수록 수렴이 더 빠르게 일어남을 확인할 수 있 다. $Q$ 는 $\mathrm{ABS}$ 구간비율을 갱신하기 전, 각 기지국에 서 사용자 전환 과정을 실행하는 횟수이므로, $Q$ 값이 작다는 것은 $\mathrm{ABS}$ 구간비율을 자주 갱신한다는 것을 의미한다. 또한, 그림에서 확인할 수 있듯이 $\mathrm{ABS}$ 구 간비율을 자주 갱신할 경우 수렴속도가 빨라지는 이 점이 존재한다. 그러나 사용자의 소속 기지국 전환이 해당 사용자 주변의 기지국들과의 정보 교환을 통해 수행되는데 반해 $\mathrm{ABS}$ 구간비율 갱신은 전체 사용자 의 수율 정보를 기반으로 수행되므로 너무 자주 $\mathrm{ABS}$ 구간 비율을 갱신하게 될 경우 시스템의 부담이 증가 한다는 단점이 존재한다.

이와 관련하여 표 2 는 $Q$ 값에 따라 수렴하는데 소 요되는 프레임 수와 $\mathrm{ABS}$ 구간비율 갱신 횟수를 나타 내었다. $Q=8$ 의 경우, $Q=4$ 인 경우와 비교하여 수 렴하는데 약 1.9 배의 프레임이 더 소요되는 반면, $\mathrm{ABS}$ 구간비율의 갱신 횟수는 거의 차이가 없다. 하지 만, $Q=1$ 인 경우와 비교했을 때, 수렴하는데 소요되 는 프레임은 약 4 배 정도 증가했으나, $\mathrm{ABS}$ 구간비율 갱신 횟수는 $50 \%$ 가 감소했다. 따라서, 시스템의 부담 을 줄이면서 적절한 수렴 속도를 보이는 $Q$ 값을 적용 할 필요가 있음을 알 수 있다.

\section{3 최적해 관련 논의}

3.1 절에서 논의한 바와 같이, 사용자 수와 기지국 수가 증가하면 발생 가능한 사용자-소속 기지국 조합 이 수는 지수적으로 증가하며, 최적해를 찾기 위해서 


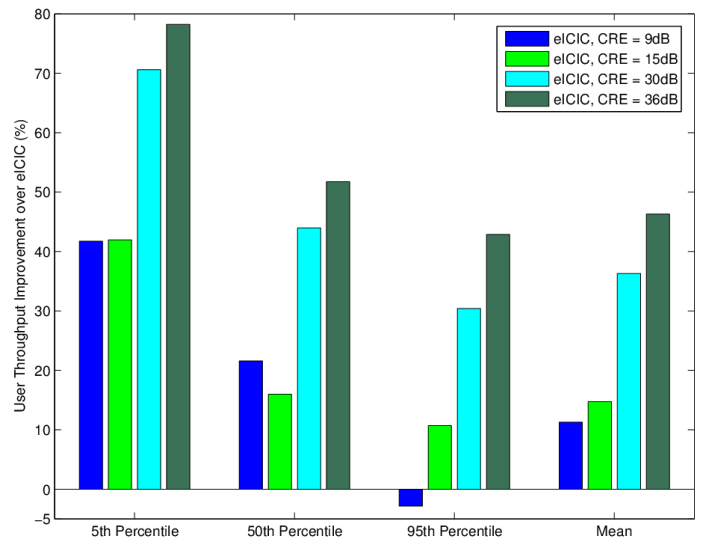

그림 8. eICIC 기법 대비 제안 기법 $(M=25, Q=1)$ 의 사 용자 수율 향상율

Fig. 8. User Throughput performance improvement over $\operatorname{eICIC}(M=25, Q=1)$

는 모든 조합을 확인해야하므로 최적해를 구하는 것 은 현실적으로 불가능하다. 따라서, 최적해를 구하는 대신 경험적으로 최적해에 가까운 해를 구할 수 있는 것으로 알려진 유전자 알고리즘을 적용하고 ${ }^{[21]}$, 그 결 과를 제안 기법과 비교하였다. 덧붙여, 유전자 알고리 즘은 자연세계의 진화과정에 기초한 계산 모델로서 생물의 진화를 모방한 진화연산의 대표적인 기법이며, 전역 탐색 알고리즘으로서 최적화 문제를 해결하는 기법중의 하나로 알려져 있다 ${ }^{[21]}$. 본 논문에서 유전자 알고리즘은 다음과 같이 동작한다. 제한된 개수의 임 의의 사용자-소속 기지국 조합을 생성하고 각 조합에 대해 로그 사용자 수율 합 (즉, 비례공정 효용함수 합) 을 계산한다. 이때, $\mathrm{ABS}$ 구간비율 값은 주어진 조합 에 대해 로그 수율 합을 최대화하는 값을 선택한다. 이러한 조합들 중 로그 수율 합이 큰 소수의 조합만을 다음 세대에 생존하는 조합으로 선택한다. 다음 세대 에는 생존한 조합들, 생존한 조합들을 이용하여 생성 한 조합들, 그리고 새로 생성되는 임의의 조합들에 위 와 같은 과정을 다시 수행한다. 이러한 과정을 지속적 으로 반복하여 최적에 가까운 조합을 찾아낸다.

그림 6은 유전자 알고리즘에 대한 제안 기법의 로 그 사용자 수율 합의 감소율 및 사용자-소속 기지국 조합의 차이에 대한 누적확률분포 함수를 보여준다. 여기서, 유전자 알고리즘의 결과는 독립적으로 생성된 25 개의 사용자 및 스몰 셀 기지국 분포에 대하여 10,000 세대 동안 실행하여 얻은 결과이다. 두 기법의 사용자-소속 기지국 조합의 차이가 최대 $5 \%$ 까지 발생 하는데 비해 로그 사용자 수율 합의 감소율은 최대 약 $0.05 \%$ 이내 이므로, 제안 기법이 유전자 알고리즘의

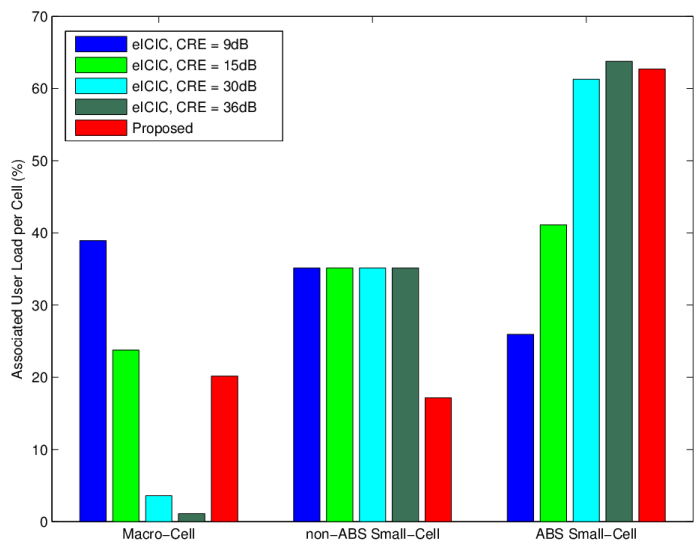

그림 9. 셀 종류별 소속 사용자 비율

Fig. 9. Associated user load per cell

성능에 상당히 근접했음을 알 수 있다. 그 이유는, 제 안 기법의 경우 초기부터 가장 높은 로그 사용자 수율 합이 예상되는 사용자부터 소속 기지국 전환을 수행 하므로, 유전자 알고리즘에 의한 추가적인 로그 사용 자 수율 합의 증가는 크지 않기 때문이다.

\section{4 사용자 수율 성능 비교}

본 절에서는 $\mathrm{eICIC}$ 기법과의 비교를 위해, 매개변 수 $M=25$ 와 $Q=1$ 을 제안 기법에 적용하였다. 그림 7은 제안 기법과 다양한 문턱치 값을 적용한 $\mathrm{eICIC}$ 기법들의 사용자 수율에 대한 누적확률분포 함수를 보여준다. 4.1 절에서 언급한 바와 같이 $\mathrm{eICIC}$ 기법은 로그 사용자 수율 합이 최대가 되도록 $\mathrm{ABS}$ 구간비율 을 적응적으로 적용했다. 이 그림을 통해, 모든 $\mathrm{CRE}$ 문턱치 값에 대한 제안 기법이 대부분의 사용자 수율 성능을 향상 시킬 수 있으나, 높은 사용자 수율 영역 에서는 제안 기법의 수율 성능이 eICIC 기법의 수율 성능에 비해 약간 열화 되었음을 확인할 수 있다.

그림 8과 그림 9는 각각 다양한 $\mathrm{CRE}$ 문턱치 값을 적용한 eICIC 기법과 제안 기법의 5 번째, 50 번째, 95번째 백분위 사용자, 평균 사용자 수율 향상율과 셀 종류별 평균 사용자 비율을 보여준다. 그림 8 에서, 제 안 기법은 $\mathrm{eICIC}$ 기법(CRE $=9 \mathrm{~dB})$ 에 비해 하위 5 번 째, 50 번째, 백분위 사용자 및 평균 사용자 수율 관점 에서 약 $42 \%, 22 \%, 11 \%$ 로 각각 증가했으며, 하위 95 번째 백분위 사용자 수율은 약 $3 \%$ 감소했다. CRE 문 턱치 값이 $9 \mathrm{~dB}$ 인 eICIC 기법을 제외한 경우, 제안 기 법은 eICIC 기법에 비해 하위 5 번째, 50 번째, 95 번 째 백분위 사용자 및 평균 사용자 수율 관점에서 최소 약 $42 \%, 16 \%, 11 \%, 15 \%$ 의 증가율을 각각 보였다. 또한, 그림 8 을 통해서 $\mathrm{CRE}=15 \mathrm{~dB}$ 부터, $\mathrm{CRE}$ 문턱 


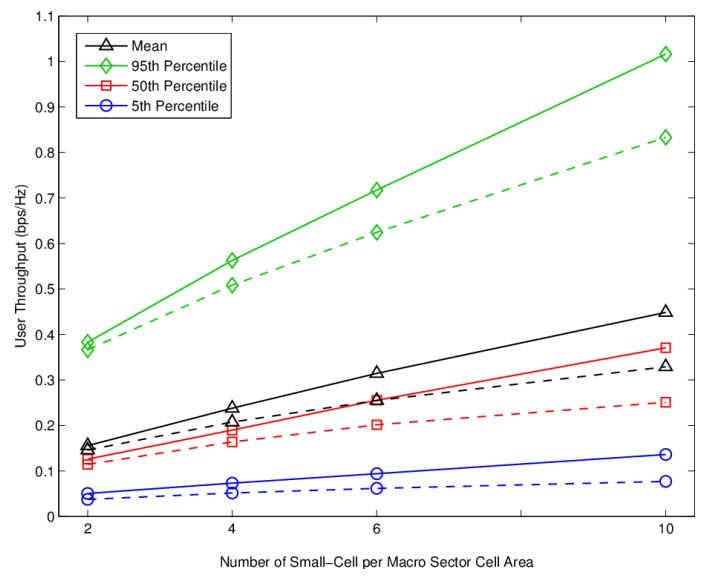

그림 10. 매크로 섹터 셀 당 스몰 셀 개수에 따른 $\mathrm{eICIC}$ 기법 $(\mathrm{CRE}=15 \mathrm{~dB}$, 점선 $)$ 및 제안 기법 $(M=25, Q=1$, 실 선)의 수율 성능

Fig. 10. User throughput performance versus number of small-cells per macro sector cell area. Solid and dashed lines represent the proposed scheme with $Q=1$ and $M=25$ and eICIC scheme with $\mathrm{CRE}=15 \mathrm{~dB}$ respectively

치 값이 증가할수록 $\mathrm{eICIC}$ 기법의 수율성능이 열화되 는 것을 확인할 수 있다. 그 이유는 다음과 같이 설명 할 수 있다. 그림 9에서, 제안 기법은 $\mathrm{eICIC}$ 기법과 비교하여 최대 약 $50 \%$ 의 매크로 사용자를 스몰 셀로 분산시킴으로써, 매크로 셀의 부하를 감소시켰음을 알 수 있다. 특히, $\mathrm{eICIC}$ 기법 $(\mathrm{CRE}=36 \mathrm{~dB})$ 은 제안 기 법에 비해 더 많은 사용자를 $\mathrm{ABS}$ 구간을 사용하는 스몰 셀로 분산시켰으나, 그림 8의 결과로부터 수율 성능은 오히려 크게 감소하였음을 확인할 수 있다. 이 경우와 같이 $\mathrm{CRE}$ 문턱치 값이 극단적으로 증가하게 되면 매크로 셀에서 스몰 셀로 소속 셀을 전환하는 사 용자가 크게 증가하여, 오히려 스몰 셀에 너무 많은 사용자가 집중되는 현상이 발생한다. 이로 인해 매크 로 셀을 소속 셀로 선택 했을 때, 좋은 수율 성능을 가 질 수 있는 다수의 사용자들도 $\mathrm{CRE}$ 에 의해 강제로 $\mathrm{ABS}$ 구간을 사용하는 스몰 셀로 소속 셀을 전환함으 로써, 수율 성능이 저하되고, 동시에 매크로 셀에 의 한 간섭을 피하고 수율성능 향상을 위해 $\mathrm{ABS}$ 구간을 사용하는 스몰 셀로 소속 셀을 전환한 사용자들도 동 일한 기지국에 소속된 사용자들의 증가로 인해 오히 려 수율성능이 더 감소된다.

또한, $\mathrm{CRE}$ 문턱치 값에 따라 $\mathrm{eICIC}$ 기법의 매크로 셀과 $\mathrm{ABS}$ 구간을 사용하는 스몰 셀의 사용자 비율은 변화하지만 non-ABS 구간을 사용하는 스몰 셀 사용 자의 비율은 일정함을 알 수 있다. 그 이유는 CRE 문 턱치 값이 증가할수록 $\mathrm{ABS}$ 스몰 셀로 소속 셀을 전
환하는 사용자는 증가하게 되지만, 스몰 셀 기지국으 로부터 수신신호가 가장 강하게 수신되는 사용자들은 $\mathrm{CRE}$ 값에 의한 영향을 받지 않으므로 해당 사용자 비율의 변함이 없기 때문이다.

그림 10은 매크로 섹터 셀 영역 당 스몰 셀 기지국 개수 $L$ 에 따른 제안 기법과 $\mathrm{eICIC}$ 기법 $(\mathrm{CRE}=$ $15 \mathrm{~dB}$ )의 사용자 수율 성능을 보여준다. 여기서 실선 과 점선은 각각 제안 기법과 eICIC 기법의 성능을 나 타낸다. 이 그림을 통해, $L$ 값이 증가함에 따라 제안 기법의 사용자 수율 성능이 eICIC 기법의 사용자 수 율 성능보다 더 빠르게 증가함을 확인할 수 있다. 구 체적으로 $L$ 값이 2 에서 10 으로 증가하는 동안 하위 5 번째 백분위 사용자의 수율은 eICIC 기법 $105 \%$, 제 안 기법 $169 \%$ 증가했으며, 하위 50 번째 백분위 사용 자의 수율은 eICIC 기법 $120 \%$, 제안 기법 $190 \%$ 로 증가했다. 그리고 하위 95 번째 백분위 사용자 수율에 서는 $\mathrm{eICIC}$ 기법 $127 \%$, 제안 기법 $165 \%$ 의 증가율를 보이고 있으며, 평균 사용자 수율 관점에서는 $\mathrm{eICIC}$ 기법 $125 \%$, 제안 기법 $188 \%$ 증가율을 나타내었다. 이 를 통해서, $L$ 값이 증가할수록 제안 기법이 사용자 부 하를 더욱 효과적으로 분산시킬 수 있음을 의미한다.

\section{V. 결 론}

본 논문에서는 $\mathrm{eICIC}$ 기법이 적용된 이종 셀룰러 망에서 매크로 셀에 집중된 사용자 부하를 스몰 셀로 분산시켜, 사용자들에게 비례적으로 공정하게 서비스 를 제공하는 부하 분산 기법을 제안하였다. 기존의 $\mathrm{eICIC}$ 기법에서는 CRE 만을 이용하여 사용자 부하를 분산시켰기 때문에 그 성능에 한계가 있었다. 이를 해 결하기 위해 제안된 기법은 탐욕 알고리즘 기반의 소 속 기지국 전환과 $\mathrm{ABS}$ 구간비율 갱신을 재귀적으로 결합하여 전체 사용자 수율의 비례공정을 향상시켰다. 구체적으로, 시스템 레벨 시뮬레이션을 통해 제안된 기법이 기존의 eICIC 기법에 비해 5 번째 백분위 사 용자 수율이 최소 약 $42 \%$ 이상 증가했음을 확인하였 다. 또한, 스몰 셀 기지국이 증가함에 따라 사용자 부 하를 더욱 효과적으로 분산시킬 수 있음을 확인하였 다. 본 연구는 모든 사용자의 위치가 정적이라는 가정 하에 연구되었다. 따라서, 사용자의 위치가 실시간으 로 변화하는 환경을 고려한 연구가 추가적으로 필요 할 것이다. 


\section{References}

[1] Cisco, Cisco visual networking index: Global mobile data traffic forecast update, 2012-2017, Cisco white paper, Feb. 2013.

[2] A. Ghosh, R. Ratasuk, B. Mondal, N. Mangalvedhe, and T. Thomas, "LTE-advanced: Next-generation wireless broadband technology," IEEE Wirel. Commun., vol. 17, no. 3, pp. 10-22, Jun. 2010.

[3] B. Soret, H. Wang, K. I. Pedersen, and C. Rosa, "Multicell cooperation for LTE-Advanced heterogeneous network scenarios," IEEE Wirel. Commun., vol. 20, no. 1, pp. 27-34, Feb. 2013.

[4] S. Y. Kim, H. W. Lee, and S. W. Ryu, "Analytical evaluation of almost blank subframes for heterogeneous networks," J. KICS, Vol. 38, no. 4, pp. 240-246, Apr. 2013.

[5] H. J. Kim, Y. H. Jo, J. C. Lim, and D. H. Hong, "Interference mitigation by joint employment of power control and almost blank subframes in heterogeneous networks," J. KICS, vol. 39, no 1, pp. 62-64, Jan. 2014.

[6] S. Lembo, P. Lunden, O. Tirkkonen, and K. Valkealahti, "Optimal muting ratio for enhanced inter-cell interference coordination (eICIC) in HetNets," in Proc. IEEE ICC, Budapest, Hungary, pp. 1145-1149, Jun. 2013.

[7] J. Pang, J. Wang, D. Wang, G. Shen, Q. Jiang, and J. Liu, "Optimized time-domain resource partitioning for enhanced inter-cell interference coordination in heterogeneous networks," in Proc. IEEE Wirel. Commun. Net., Shanghai, China, pp. 1613-1617, Apr. 2012.

[8] L. Jiang and M. Lei, "Resource allocation for eicic scheme in heterogeneous networks," in Proc. IEEE Personal, Indoor and Mobile Radio Commun., Sydney, Australia, pp. 448-453, Sept. 2012.

[9] S. Vasudevan, R. N. Pupala, and K. Sivanesan, "Dynamic eICIC - a proactive strategy for improving spectral efficiencies of heterogeneous LTE cellular networks by leveraging user mobility and traffic dynamics," IEEE Trans. Wirel. Commun., vol. 12, no. 10, pp. 4956-4969,
Oct. 2013.

[10] S. E. Kim, K. S. Kim, and E. K. Hon, "Analysis on interference control in heterogeneous networks," J. KICS, vol. 38, no. 3, pp. 268-276, Mar. 2013

[11] Y. Wang, B. Soret, and K. I. Pedersen, "Sensitivity study of optimal eICIC configurations in different heterogeneous network scenarios," in Proc. IEEE Commun., Ottawa, ON, pp. $6792-$ 6796, Jun. 2012.

[12] A. Tall, Z. Altman, and E. Altman, "Self organizing strategies for enhanced ICIC (eICIC)," submitted to WiOpt 2014, Jan. 2014, from http://arxiv.org/pdf/1401.2369v1.pdf

[13] T. F. Gonzalez, Handbook of Approximation Algorithms and Metaheuristics, Chapman \& Hall, 2007.

[14] Y. Choi and S. Bahk, "Cell-throughput analysis of the proportional fair scheduler in the single-cell environment" in Proc. IEEE VTC, vol. 56, no. 2, pp. 766-778, Mar. 2007.

[15] P. Viswanath, D. Tse, and R. Laroia, "Opportunistic beamforming using dumb antennas," IEEE Trans. Inf. Theory, vol. 48, no. 6, pp. 1277-1294, Jun. 2002.

[16] 3GPP TR 36.814 v9.0.0, "Further advancements for E-UTRA physical layer aspects (Release 9)," Technical Report 3GPP, Mar. 2010.

[17] Y. Wang and K. I. Pedersen, "Performance analysis of enhanced inter-cell interference coordination in LTE-advanced heterogeneous network," in Proc. IEEE VTC, Yokohama, Japan, pp. 1-5, May 2012.

[18] A. Damnjanovic, J. Montojo, Y. Wei, T. Ji, T. Luo, M. Vajapeyam, T. Yoo, O. Song, and D. Malladi, "A survey on heterogeneous networks," IEEE Trans. Wirel. Commun., vol. 18, no. 3, pp. 10- 21, Jun. 2011.

[19] H. Holma and A. Toskala, LTE for UMTS OFDMA and SC-FDMA based Radio Access, Wiley, 2009.

[20] P. Svedman, S. K. Wilson, L. J. Cimini, Jr., and B. Ottersten, "Opportunistic beamforming and scheduling for OFDMA systems," IEEE Trans. Commun., vol. 55, no. 5, pp. 941-952, May 2007.

[21] S. N. Sivanandam and S. N. Deepa, Introduction 
to Genetic Algorithm, Springer, 2007.

홍 명 훈 (Myung-hoon Hong)

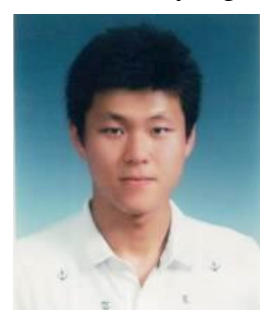

2013년 2월: 강원대학교 전자 통신공학과 졸업

2013년 3월 현재 : 강원대학교 전자통신공학과 석사 <관심분야> 무선 네트워크, 이 동통신, $\mathrm{LTE}$
박 승 영 (Seung-young Park)

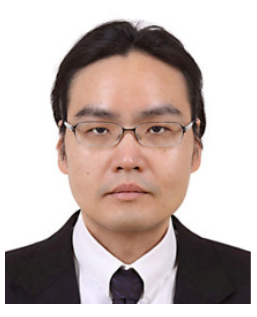

1997년 2월 : 고려대학교 전파공 학과 졸업

1999년 2월 : 고려대학교 통신시 스템학과 석사

2002년 8월 : 고려대학교 전파공 학과 박사

2002년 11월 2003년 3월: 고려 대학교 BK21 정보통신사업단 박사후연구원

2003년 4월 2005년 12월 : 삼성전자종합기술원 책임 연구원

2006년 1월 2007년 2월 : 미국 퍼듀대학교 박사후연 구원

2012년 1월 2013년 1월: 미국 퍼듀대학교 방문교수 2007년 3월 현재: 강원대학교 전자통신공학과 부교수 <관심분야> 이동통신, 다중안테나/다중사용자 통신, 무선자원관리 